Relations industrielles

Industrial Relations

\title{
Kelly, John, and Edmund Heery, Working for the Union: British Trade Union Officers
}

\section{Norman A. Solomon}

Volume 50, numéro 3, 1995

URI : https://id.erudit.org/iderudit/051043ar

DOI : https://doi.org/10.7202/051043ar

Aller au sommaire du numéro

Éditeur(s)

Département des relations industrielles de l'Université Laval

ISSN

0034-379X (imprimé)

1703-8138 (numérique)

Découvrir la revue

Citer ce compte rendu

Solomon, N. A. (1995). Compte rendu de [Kelly, John, and Edmund Heery, Working for the Union: British Trade Union Officers]. Relations industrielles / Industrial Relations, 50(3), 666-668. https://doi.org/10.7202/051043ar

Tous droits réservés (C) Département des relations industrielles de l'Université Laval, 1995
Ce document est protégé par la loi sur le droit d'auteur. L'utilisation des services d'Érudit (y compris la reproduction) est assujettie à sa politique d'utilisation que vous pouvez consulter en ligne.

https://apropos.erudit.org/fr/usagers/politique-dutilisation/ 
québécois dans les années à venir. L'auteure montre de façon précise que le mouvement syndical est le produit de son passé et qu'il se retrouve aujourd'hui, avec les restructurations qui ont lieu dans les entreprises et l'ouverture des marchés, en contradiction avec certaines valeurs véhiculées par son héritage. En ce sens, deux grands défis se posent au syndicalisme québécois. Primo, il doit s'assurer d'être un acteur sociopolitique majeur à tous les plans; secundo, il doit simultanément supporter un projet social et un projet national qui soit émancipateur. Et cela se joue dans un contexte d'incertitude politique dominé par la question nationale.

Pour terminer, disons que l'auteure remplit de façon honnête le mandat qu'elle s'était fixée en début de livre à savoir, fournir les éléments nécessaires à une réflexion sur le passé, le présent et l'avenir du syndicalisme. Publié dans une collection qui s'adresse à un large public, l'ouvrage possède la qualité indéniable d'éclairer sous un angle nouveau le rôle politique du mouvement syndical, une facette sur laquelle d'autres ouvrages passent souvent trop rapidement et qui est généralement méconnue du grand public. Pour la même raison, cet ouvrage pourrait être utile aux étudiantes et étudiants de relations industrielles qui abordent pour la première fois la question du syndicalisme. Ils y trouveront certainement matière pour stimuler une réflexion critique sur l'avenir du syndicalisme.

MiCHÈLE BILODEAU

Université Laval

\section{Working for the Union: British Trade Union Officers}

by John KELLY and Edmund HEERY, Cambridge, England, Cambridge University Press, 1994, 228 p., ISBN 0-521-38320-X.

This book is destined to become a classic of the industrial relations literature. It is the only volume that 1 know of using multiple research methods to study the activities of trade union officers. Based on the data thus collected the authors develop conclusions which seriously challenge some of the traditional theories of how trade unions operate including the widely accepted theory of trade union bureaucracy.

This review will discuss the following aspects of the volume: the research methodology used; the main topics covered; the key themes set forth; and the significance of this work to industrial relations.

The rigour and thoroughness of the research methodology are impressive. During the period 1985 through 1991 the authors observed 27 local trade union officers from four different unions at work. Detailed records were kept of the meetings and activities of these officers over a one year period. This observation data was coded and subsequently statistically analyzed. This data was supplemented by three questionnaire surveys to a population of 273 officers in the original four unions and in three additional unions. This data was also coded and statistically analyzed. These analyses were used throughout the volume to support the basic themes which focused on officer values as key determinants of officer actions.

Unfortunately however the quantitative results are presented in such a way that only advanced students of industrial relations would have the fortitude to plow through the detailed statistical analysis in each chapter. This is unfortunate because the data paint a fascinating picture of British trade unionism and one that would be of interest to a more general readership. The volume could have been made more 'reader friendly' by either putting more of the quantitative 
analysis in a separate chapter or by having a much more extensive appendix on research methods.

Substantively the volume is divided into four parts: Part 1 provides us with an introduction; Part 2 describes the parameters of union work; Part 3 provides a detailed discussion of the work performed by the full-time trade union officer in Britain; and Part 4 provides the authors conclusions.

A key focus of Part 1 is an in-depth look at theories of trade union organization starting with the Webbs. Kelly and Heery provide an excellent analysis of the theories of bureaucracy, oligarchy and polyarchy as they apply to union organization. While acknowledging that many of the structural constraints set forth in these theories do exist in unions and do limit the actions of trade union officers the authors argue that the values of union officers are most important in determining their actions and objectives.

Part 2 provides a rich description of the organization of full-time officers within the unions studied. The topics covered in this section include: the background of officers and their route into the job; the different routes of men and women and of officers working for white-collar versus blue collar unions; the terms and conditions of employment of union officers; the workloads of the officers; and the way in which senior officers monitor and evaluate the activities of their subordinates.

A key conclusion of Part 2 is that local union officers in fact are subject to limited control by their superiors. The authors point out that given the rather small number of union officers available to service a large number of members the national officers must trust the good judgement of their subordinates. As the authors state this trust is most often borne out with local officers displaying a high level of dedication to the union.
The way in which the officers carried out their jobs often differed however. Kelly and Heery argue that the values and ideologies of the local officers explain these differences in approach. For example, the authors found that it is more likely that union officers who place themselves on the political 'right' will act like union bureaucrats by exerting high control over the collective bargaining process and by down playing the importance of reporting to lay representatives of the union. Those officers on the political 'left' saw themselves as more accountable to lay representatives and also as more interested in pursuing equality issues in collective bargaining.

In Part 3 the authors focus on four issues: organizing; bargaining objectives; the bargaining process; and dealing with managers. Using data gathered for this section the authors group officers into three categories based on their goal ambitions, willingness to use sanctions, hostility to management and the use of stewards to mobilize members. The three categories of officers are managerialist, regulationist and leader. Managerialists were the 'old guard' of the union and were generally in the above 50 year old age group. These officers tended to be more bureaucratic than the younger 'leader' group which had come of age during the political tumult of the 1960 s and 1970s. The latter group, not surprisingly took a more political view of trade union work and sought to enhance the overall outlook and ambition of their members. The regulationists fit between the other two groups and tended to be more pragmatic than the leader group but not as conservative as the managerialists. They adjusted more readily to the balance of power at the workplace and were more likely to view employers as critical to workplace governance. The authors conclude that there is a strong generational effect that impacts on how officers do their job with this effect having a dramatic effect on values and beliefs. 
In Part 4 the authors provide a comprehensive summary of their conclusions. In this section the authors offer explanations for the generational impact on values. Kelly and Heery argue that many of their findings can be traced to the fact that a number of contemporary officers were shop stewards during the 1960 s and 1970s. This was a period when stewards exhibited a great deal of militancy. Thus strong support for workplace organization, a belief in the need for steward independence, encouragement of ambitious bargaining objectives and a deep mistrust of management all flow from the strong workplace organization and adversarial industrial relations system present in Britain in the 1970s. The authors state that if their conclusions about generational impact on values hold true then it is fair to ask whether officers appointed in the near future will show less militancy than current officers. Kelly and Heery argue that it may well be that - especially in the private sector where strike incidence has declined greatly during the 1980 s newer officers will display a greater willingness to cooperate with management than did their predecessors.
In conclusion this book belongs on the shelf of every serious industrial relations scholar. It should be required reading for graduate students. The main theme of this volume, that values-as determined by age or generational differences-determine the activities of trade union officers has tremendous implications for trade unionists and trade union scholars in North America. North American scholars studying trade unions now have a blue print to follow in designing a study to analyze factors determining the actions of North American trade union officers. Much of the North American research in the area of trade union governance starts out with acceptance of bureaucracy theory as an explanation for how trade unions function. From my perspective the most important contribution of this volume is to force North American scholars to reconsider this assumption. Kelly and Heery have laid out the path, it is now up to us to follow it and begin an in-depth parallel study of trade union officers on this continent.

NORMAN A. SOLOMON University of Windsor

\section{La résolution des griefs dans l'entreprise}

par Jean-Claude BERNATCHEZ, Trois-Rivières, CIRIM Éditeur, 1994, 428 p., ISBN 2-9802036-5-3.

Cet ouvrage vise à décrire les mécanismes de résolution des litiges (MRL) en contexte syndiqué ou non syndiqué. Le premier chapitre expose un cadre de référence dans lequel les litiges sont définis comme étant des plaintes ou des griefs qui surviennent lorsqu'il y a un écart sur la façon de percevoir une situation et de la résoudre. Des personnes sont mandatées pour régler ces litiges et trouver une solution durable en autant que les réalités internes de l'entreprise aient été prises en considération, notamment, les valeurs organisationnelles, les droits et les obligations des parties.
Le chapitre 2 porte sur les griefs et la gestion des ressources humaines (GRH). Les domaines étudiés dans cette partie touchent la période de probation des nouveaux employés, la dotation, l'ancienneté, les mouvements de personnel, la rémunération globale et la santé au travail. Les gestionnaires sont préoccupés par ces domaines de la GRH, puisqu'ils ont des conséquences sur la productivité des personnes et de l'organisation, en plus de faire fréquemment l'objet de griefs selon l'auteur.

Le chapitre 3 met en lumière la conduite des parties, en vue de maintenir des relations de travail efficaces sur 